\title{
Editorial - 'Seeds of illumination in a sometimes dry landscape'
}

\author{
Shayne Walker
}

Kia ora koutou, ngā mihi aroha ki a koutou katoa:

Thanks to those who have contributed to this double edition; there are four articles on 'supervision' and four of a general nature, it's great to get Te Komako growing again! The learning and practice that has emanated from past issues of Te Komako is phenomenal. When I started my formal social work education, articles from Te Komako were like 'seeds of illumination in a sometimes dry landscape'. Mixed metaphors aside, those articles acknowledged my Māoriness and enhanced my thinking and practice. Te Komako has been and is a tool of 'conscientisation' (Friere, 1972) and was very much part of my own emancipation. It stands alongside Puao-Te-Ata-Tu (Ministerial Advisory Committee, 1986), as a series of seminal works that have shaped Maori social work provision, education and practice. I congratulate, and am grateful to, the ANZASW membership for having the vision to see this as important.

I want to acknowledge the hard work and commitment of those who have gone forth before us in terms of making Te Komako happen. To all of those involved in the process, from submission to editing to typesetting to printing and then distribution, thank you for your hard work on behalf of Māori who have benefited from your work. The mana of your mahi goes forth before you and many of us are still inspired by articles, some of which are almost 20 years old.

I would also like to acknowledge the contributors, those who have chosen to put themselves out there in terms of Māori practice and theory. Leland Ruwhiu (2009) talks about 'mana enhancing practice' when working with others. Your contributions in Te Komako have the capacity to enhance the mana of practitioners, educators, students and ultimately the whanau they work with.

We are hoping to hear from as wide a group of practitioners as possible. We intend to publish a mix of research, commentary and practice-based articles. We have been asked to produce an edition on 'whanau-centred practice'; if you can contribute, please contact us. You may not think you write well or that your ideas are important, but please have the courage to send your articles in, as we can help fine-tune if necessary, or suggest ways that they can be developed further. We have gathered together a group of reviewers who will give you honest feedback and we are committed to ensuring that another edition of Te Komako is produced in September 2013. If you have any ideas about possible 'themes' for the journal or people you know who could contribute but just need a little push, please get in touch.

I look forward to hearing from you at shayne.walker@otago.ac.nz, or you can also contact Anaru Eketone at anaru.eketone@otago.ac.nz. 
Thank you also to Heremaahina Eketone (an artist and qualified social worker) for the artwork on the cover. The right-hand side is inspired by Emma Webber-Dreadon's Awhiowhio cultural supervision framework (1997) and the left-hand side represents the wairuatanga that supports us in our work.

Ngā mihi nui.

\section{References}

Dreadon, E. (1997). Matua whakapai tou marae, ka whakapai ai i te marae o te tangata: First set in order your own marae before you clean another. Te Komako, Social Work Review, 8(1).

Friere, P. (1972). The pedagogy of the oppressed. Middlesex: Penguin.

Ministerial Advisory Committee. (1986). On a Maori Perspective to the Department of Social Welfare Puao-Te-Ata-Tu (Daybreak). Wellington: Government Printer.

Ruwhiu, L. (2009). Indigenous issues in Aotearoa New Zealand. In M. Connolly \& L. Harms (Eds). Social Work Contexts and Practice (pp. 107-120). Australia New Zealand: Oxford University Press. 